\title{
Deskripsi sikap siswa SMA di Batanghari berdasarkan indikator normalitas ilmuwan, adopsi dari sikap ilmiah, ketertarikan memperbanyak waktu, dan ketertarikan berkarir di bidang fisika
}

\author{
Astalini, Dwi Agus Kurniawan, dan Linda Zaenati Nur Farida \\ Pendidikan Fisika, FKIP Universitas Jambi \\ J1. Lintas Jambi - Muara Bulian Km. I5, Mendalo Darat, Jambi Luar Kota, Kota Jambi, Jambi 36122 \\ Surat-e: astalini@unja.ac.id
}

\begin{abstract}
Tujuan penelitian ini adalah mendeskripsikan sikap siswa terhadap pelajaran fisika di SMA Kabupaten Batanghari, Beserta kendala yang dihadapi. Penelitian ini adalah penelitian kualitatif kuantitatif dengan prosedur penelitian survei. Subjek penelitian ini adalah 926 siswa SMA di Kabupaten Batanghari. Instrumen yang digunakan berupa angket dan lembar wawancara. Analisis data kuantitatif menggunakan descriptive statistic sedangkan analisis data kualitatif menggunakan teknik analisis data model Miles dan Huberman. Hasil dari 4 aspek indikator sikap yang dibahas pada penelitian ini adalah pada Indikator normalitas ilmuwan sebesar 8.3 $\%$ berkategori baik. Sedangkan adopsi dari sikap ilmiah sebesar $74 \%$ berkategori baik. Kemudian pada indikator ketertarikan memperbanyak waktu belajar fisika sebesar $57.9 \%$ siswa berkategori cukup, dan pada indikator ketertarikan berkarir di bidang fisika sebanyak $45 \%$ siswa juga berkategori cukup.
\end{abstract}

\begin{abstract}
This study is to find out the description of students' attitudes toward physics subjects in Batanghari District High School, along with the constraints faced. This research is quantitative-qualitative research with survey research procedure. The subject of this research is 926 high school students in Batanghari District. The instruments used were questionnaires and interview sheets. Quantitative data analysis uses descriptive statistics while qualitative data analysis uses data analysis techniques modeled by Miles and Huberman. The results of the 4 aspects of attitude indicators discussed in this study are on indicators of normality of science as much as $58.3 \%$ in the good category. While the adoption of scientific attitudes as much as $74 \%$ categorized well. Then on the indicator of interest in increasing the time to study physics as much as $57.9 \%$ of students are categorized sufficiently, and on the indicator of interest in a career in the field of physics as much as $45 \%$ of students are also categorized as sufficient.
\end{abstract}

Kata kunci: sikap, sikap ilmiah, fisika, sains

\section{Pendahuluan}

Fisika adalah ilmu sains yang mempelajari alam dan gejala-gejalanya secara logis, empiris, dan sistematis, melibatkan proses dan sikap ilmiah untuk memahami pokok-pokok bahasan dalam fisika [I]. Di SMA, fisika menjadi mata pelajaran pokok bagi siswa jurusan Ilmu Pengetahuan Alam (IPA). Meski memiliki banyak terapannya, siswa masih kesulitan untuk memahami fisika, dan menyebabkan minat serta motivasi belajar siswa berkurang [2]. Perilaku baik maupun perilaku buruk siswa yang ditunjukkan terhadap mata pelajaran fisika merupakan bentuk dari perwujudan dari sikap siswa.
Perasaan siswa terhadap mata pelajaran akan diafeksikan melalui sikap yang ditunjukannya selama mempelajari mata pelajaran tersebut. Oleh karena itu, sikap yang muncul baik sikap positif maupun sikap negatif dalam belajar dapat mencerminkan ketertarikan ataupun kesenangan siswa pada materi yang diajarkan. Sikap juga bisa menunjukkan berhasil tidaknya siswa menangkap materi pelajaran yang diajarkan.

Umumnya siswa menganggap fisika sebagai momok yang cukup menakutkan karena mata pelajaran tersebut menggabungkan antara ilmu sains yang komplek dengan ilmu matematika yang rumit. Hal tersebut dapat mempengaruhi prestasi dan pencapaian siswa dalam belajar fisika. Ref. [3] mengatakan, sikap negatif siswa 
terhadap pembelajaran fisika dapat mempersulit siswa pada pembelajaran kedepannya. Anggapan seperti fisika merupakan mata pelajaran yang sulit dan menakutkan akan membuat siswa menjadi apatis, pesimis dan malas untuk mempelajarinya. Sikap siswa terhadap mata pelajaran fisika dapat dilihat dalam beberapa aspek indikator sikap seperti normalitas ilmuwan, adopsi dari sikap ilmiah, ketertarikan siswa memperbanyak waktu belajar fisika dan ketertarikan untuk berkarir di bidang fisika.

Aspek normalitas ilmuwan mendeskripsikan bagaimana siswa melihat para ilmuwan dan menempatkan dirinya sebagai pembelajar sains. Adopsi dari sikap ilmiah mengukur kesediaan dan kesiapan siswa memberi respon ilmiah serta keterbukaan siswa terhadap suatu informasi baru. Aspek ketertarikan memperbanyak waktu belajar fisika dapat menunjukkan seberapa ketertarikan dan kesungguhan siswa dalam memahami pelajaran fisika. Sedangkan aspek ketertarikan untuk berkarir di bidang fisika dapat mendeskripsikan seberapa besar minat siswa dan kepercayaan diri siswa untuk mempelajari fisika kedepannya.

Berdasarkan observasi yang dilakukan di SMA daerah Batanghari, siswa cenderung menganggap fisika adalah mata pelajaran yang sulit untuk dipahami dan menakutkan, sehingga mempelajari fisika menjadi seperti beban berat bagi siswa. Siswa juga menjadi apatis dalam kelas. Oleh karena itu, tujuan dari penelitian ini adalah untuk mengetahui sikap siswa di SMA daerah Batanghari melalui aspek normalitas ilmuwan, adopsi dari sikap ilmiah, ketertarikan memperbanyak waktu belajar fisika, dan ketertarikan berkarir di bidang fisika.

Hasil temuan dari penelitian ini berkontribusi dalam meningkatkan pembelajaran fisika melalui sikap siswa. Dengan sistem pendidikan Indonesia yang lebih mengutamakan karakter siswa, maka penelitian ini dapat membantu menjabarkan deskripsi sikap terutama untuk sikap siswa SMA.

\section{Kajian Pustaka}

\section{Sikap}

Sikap merupakan gabungan komponen kognitif, afektif, serta perilaku seseorang[4]. Sikap juga berhubungan dengan pengelolaan emosi dalam pembelajaran dan mengarahkan perilaku manusia [5]. Sikap berfungsi memenuhi kebutuhan psikologis dalam memahami apapun dilingkungannya, baik positif ataupun negatif, mengidentifikasi orang-orang yang disukai ataupun yang tidak, dan mempertahankan diri dari konflik-konflik internal [6]. Sikap negatif terhadap suatu mata pelajaran dapat memperburuk kinerja dan kemampuan siswa serta mengurangi kepercayaan diri untuk mempelajarinya [7].
Deskripsi sikap siswa SMA di Batanghari berdasarkan indikator normalitas ilmuwan, adopsi dari sikap ilmiah, ketertarikan memperbanyak waktu, dan ketertarikan berkarir di bidang fisika

\section{Normalitas Ilmuwan}

Suatu gambaran terhadap seorang ahli ilmu pengetahuan disebut juga dengan persepsi terhadap saintis. Persepsi terhadap saintis ini mempengaruhi minat siswa untuk mempelajari sains [8]. Persepsi siswa terhadap para ilmuwan umumnya stereotip [9]. Siswa seringkali menganggap ilmuwan yang mempelajari fisika sebagai orang yang terlahir jenius dan bisa dalam segala bidang ilmu dan eksentrik. Ilmuwan digambarkan sebagai orang tua berjas putih yang selalu bekerja di laboratorium, menemukan hal-hal baru dan membaca banyak buku [IO].

\section{Adopsi dari Sikap Ilmiah}

Sikap ilmiah dimaknai sebagai sikap yang perlu dimiliki saintis misalnya seperti rasa ingin tahu, jujur, tekun, menerima kebenaran lewat pembuktian atau fakta, terbuka, optimis, peduli, kreatif, dan lainnya, yang mana sikap tersebut tidak hanya berguna didalam sekolah saja tetapi juga dalam kehidupan bermasyarakat, dan membentuk kepribadian baik dari seseorang [8]. Kesiapan dan kesediaan seseorang untuk memberikan respon secara ilmiah dan sesuai hukum ilmiah yang telah diakui kebenarannya disebut juga sikap ilmiah [II]. Oleh karena itu, mengembangkan sikap ilmiah dapat membantu siswa memperoleh hasil belajar yang lebih baik [4].

\section{Ketertarikan Memperbanyak Waktu Belajar Fisika}

Memperbanyak waktu belajar fisika dapat membantu siswa untuk memahami mata pelajaran fisika lebih baik. Siswa yang terlatih untuk mengerjakan soal-soal fisika akan lebih mahir dan lebih cepat dalam memutuskan rumus atau konsep yang digunakan dalam persoalan fisika. Sehingga, Siswa yang tertarik memperbanyak waktunya untuk belajar fisika akan membuat prestasi dan hasil belajarnya lebih baik [I2]. Untuk membuat siswa mau menambah waktu mereka untuk belajar fisika perlu adanya dorongan sikap yang positif seperti kesenangan dan ketertarikan belajar. Siswa akan lebih cenderung intensif dalam belajar jika mereka senang dengan kegiatan belajar tersebut [13]. Siswa yang menyukai pelajaran fisika akan tertarik untuk belajar lebih banyak. Sedangkan siswa yang kurang menyenangi fisika tidak tertarik untuk memperbanyak waktu belajar sehingga berakibat pada kegagalan dalam mencapai keberhasilan belajar fisika [I4].

\section{Ketertarikan Berkarir di Bidang Fisika}

Keberhasilan siswa dalam belajar fisika akan membuat siswa memiliki minat untuk mempelajarinya lebih lanjut. Minat siswa terhadap sains akan mempengaruhi pilihannya berkarir dibidang sains dimasa depan [I5]. Minat dan sikap yang positif terhadap fisika akan 
Deskripsi sikap siswa SMA di Batanghari berdasarkan indikator normalitas ilmuwan, adopsi dari sikap ilmiah, ketertarikan memperbanyak waktu, dan ketertarikan berkarir di bidang fisika

meningkatkan kemungkinan siswa tertarik untuk berkarir dibidang fisika di masa depan [16]. Siswa yang kurang tertarik berkarir dibidang fisika biasanya didorong oleh faktor sikap negatif. Siswa tersebut adalah siswa yang beranggapan bahwa fisika itu membosankan dan pekerjaannya berat [I7].

\section{Metode Penelitian}

\section{Rancangan Penelitian}

Jenis penelitian ini menggunakan penelitian kualitatif dan kuantitatif. Dalam penelitian kuantitatif digunakan prosedur penelitian survei. Rancangan penelitian survei dilakukan jika peneliti mengadministrasikan survei pada sampel atau populasi untuk mendeskripsikan sikap, perilaku, pendapat, dan ciri khusus populasi [I8]. Agar lebih mendetail, penelitian jenis kualitatif juga dilakukan, yakni menggunakan teknik wawancara. Rancangan penelitian ini digunakan berdasarkan tujuan penelitian ini yaitu mengetahui deskripsi sikap siswa SMA di kabupaten Batanghari terhadap mata pelajaran fisika.

\section{Subjek penelitian}

Subjek dalam penelitian ini adalah siswa dari 5 sekolah SMA di Kabupaten Batanghari yang secara keseluruhan berjumlah 926 siswa. Sampel diambil berdasarkan teknik Total sampling. Subjek merupakan siswa kelas X, XI, dan XII dari jurusan MIA dengan komposisi 573 perempuan dan 353 laki-laki yang rata-rata berusia I5-I8 tahun.

\section{Instrumen dan prosedur penelitian}

Penelitian ini menggunakan 2 instrumen, yaitu angket dan lembar wawancara. Angket yang digunakan adalah adopsi dari penelitian Ref. [19]. Terdapat 54 pernyataan yang valid dengan skala ukur yaitu skala likert. Skala tersebut terdiri dari 5 point nilai, yaitu sangat setuju adalah 5 , setuju yaitu 4 , netral yaitu 3 , tidak setuju yaitu 2, dan sangat tidak setuju adalah I. Setiap item pernyataan merupakan perwakilan dari 7 Indikator sikap. Pada penelitian ini difokuskan pada 4 indikator dari sikap yaitu normalitas keilmuan, adopsi dari sikap ilmiah, ketertarikan memperbanyak waktu belajar, dan ketertarikan berkarir dibidang fisika. Berikut ini merupakan tabel yang menunjukkan penggolongan pernyataan berdasarkan indikator yang difokuskan.
Tabel I. Indikator Sikap

\begin{tabular}{cll}
\hline No & \multicolumn{1}{c}{ Indikator } & \multicolumn{1}{c}{$\begin{array}{c}\text { Nomor } \\
\text { Pernyataan }\end{array}$} \\
\hline I & Normalitas Ilmuan & 2,9, I6, 23, 30 \\
2 & Adopsi dari Sikap Ilmiah & 4, I I, I8, 25, 32, \\
& & 37,42 \\
3 & Ketertarikan Memperbanyak & 6, I3, 20, 27, 34, \\
& Waktu Belajar & $39,44,48$, \\
4 & Ketertarikan Berkarir & 7, I4, 2I, 28, 35, \\
& Dibidang Fisika & $40,45,49,52,54$ \\
\hline
\end{tabular}

Selain angket, data juga diambil melalui wawancara kepada siswa di setiap SMA subjek penelitian. Tujuannnya agar dapat memperoleh pandangan subjektif siswa terhadap pembelajaran fisika. Pedoman wawancara dibuat dan dikembangkan berdasarkan indikator sikap yang digunakan pada angket.

Penelitian dilakukan dengan beberapa tahap. Pada tahap pertama, proposal dibuat, dan merumuskan masalah serta variabelnya. Setelah itu peninjauan pustaka dilakukan, yakni mencari teori yang mendukung dan memperdalam pembahasan dari masalah yang diteliti agar memperoleh gambaran tentang rancangan penelitian beserta instrument yang diperlukan. Kemudian, pada tahap pengambilan data, kuisioner diberikan kepada siswa di 5 SMA kecamatan Batanghari. Dilakukan pula kepada siswa masing-masing sekolah sejumlah 30 orang yang mewakili. Dari perolehan data tersebut lalu dianalisis yaitu pengkodean data, penyaringan data yang layak dan analisis dari hasil sortir data tersebut.

\section{Analisis data}

Hasil data perolehan dideskripsikan menggunakan statistic deskriptif. Statistik deskriptif menyajikan data dalam jumlah besar yang mencakup modus, mean, median, maksimum, minimum, dan standar deviasi [20]. Analisis dilakukan menggunakan program SPSS 24 untuk memperoleh presentase, frekuensi, rata-rata dan standar deviasi data. Sedangkan data kualitatif dari wawancara dianalisis secara konten dengan menggunakan model Miles dan Huberman. 
Deskripsi sikap siswa SMA di Batanghari berdasarkan indikator normalitas ilmuwan, adopsi dari sikap ilmiah, ketertarikan memperbanyak waktu, dan ketertarikan berkarir di bidang fisika

\section{Hasil Penelitian dan Pembahasan}

\section{Normalitas Ilmuwan}

Indikator normalitas ilmuwan siswa di SMA daerah Batanghari dapat dideskripsikan oleh tabel berikut.

Tabel 2. Indikator normalitas ilmuwan

\begin{tabular}{|c|c|c|c|c|c|c|c|c|c|}
\hline \multicolumn{3}{|c|}{ Klasifikasi } & \multirow{2}{*}{$\begin{array}{l}\text { Standar } \\
\text { Deviasi }\end{array}$} & \multirow{2}{*}{ Mean } & \multirow{2}{*}{ Modus } & \multirow{2}{*}{ Median } & \multirow{2}{*}{ Min } & \multirow{2}{*}{ Max } & \multirow{2}{*}{$\%$} \\
\hline Rentang & Sikap & Jumlah & & & & & & & \\
\hline $5-8$ & Sangat tidak baik & $\mathrm{I}$ & & & & & & & O.I \\
\hline $9-12$ & Tidak baik & I6 & & & & & & & I.7 \\
\hline $13-16$ & Cukup & 369 & 2,36340 & 17,0680 & I7 & 17 & 8 & 24 & 39.8 \\
\hline $17-20$ & Baik & 469 & & & & & & & 50.6 \\
\hline $2 I-25$ & Sangat baik & $7 \mathrm{I}$ & & & & & & & 7.7 \\
\hline Total & & 926 & & & & & & & $100 \%$ \\
\hline
\end{tabular}

Tabel I memperlihatkan data tertinggi siswa yakni berjumlah $58.3 \%$ siswa berada pada kategori baik dan sangat baik. Sedangkan 39.8\% siswa lainnya dapat dikategorikan cukup. Kemudian, siswa sebanyak 1.8\% lainnya berada pada kategori tidak baik. Hal ini menunjukkan kehidupan para ilmuan masih belum tergambar jelas oleh siswa sehingga siswa masih belum bisa melihat diri sendiri sebagai ilmuan.

\section{Adopsi dari Sikap Ilmiah}

Indikator adopsi dari sikap ilmiah siswa di SMA daerah Batanghari dapat dideskripsikan oleh tabel berikut.

Tabel 3. Indikator adopsi dari sikap ilmiah

\begin{tabular}{|c|c|c|c|c|c|c|c|c|c|}
\hline \multicolumn{3}{|c|}{ Klasifikasi } & \multirow{2}{*}{$\begin{array}{l}\text { Standar } \\
\text { Deviasi }\end{array}$} & \multirow{2}{*}{ Mean } & \multirow{2}{*}{ Modus } & \multirow{2}{*}{ Median } & \multirow[b]{2}{*}{ Min } & \multirow[b]{2}{*}{ Max } & \multirow{2}{*}{$\%$} \\
\hline Rentang & Sikap & Jumlah & & & & & & & \\
\hline $7-12.5$ & Sangat tidak baik & 0 & & & & & & & 0 \\
\hline $\mathrm{I} 2.6-\mathrm{I} 8 . \mathrm{I}$ & Tidak baik & 5 & & & & & & & 0.5 \\
\hline $18.2-23.7$ & Cukup & 235 & 3,30597 & 25,7019 & 27 & 26 & 16 & 35 & 25.4 \\
\hline $23.8-29.3$ & Baik & 580 & & & & & & & 62.6 \\
\hline $29.4-35$ & Sangat baik & 106 & & & & & & & II.4 \\
\hline Total & & 926 & & & & & & & $100 \%$ \\
\hline
\end{tabular}

Pada tabel 2, menunjukkan bahwa dominan siswa berkategori baik dan sangat pada indikator adopsi dari sikap ilmiah dengan persentase $74 \%$. Sebanyak $0.5 \%$ siswa lainnya berkategori tidak baik, dan sisanya yakni $25.4 \%$ siswa berkategori netral atau cukup. Data ini menunjukkan bahwa siswa sudah memiliki pola pikir ilmiah dalam kehidupannya.

\section{Ketertarikan Memperbanyak Waktu Belajar Fisika}

Indikator Ketertarikan Memperbanyak Waktu Belajar Fisika di SMA daerah Batanghari dapat dilihat pada tabel dibawah.

Tabel 4. Indikator Ketertarikan Memperbanyak Waktu Belajar Fisika

\begin{tabular}{|c|c|c|c|c|c|c|c|c|c|}
\hline \multicolumn{3}{|c|}{ Klasifikasi } & \multirow{2}{*}{$\begin{array}{l}\text { Standar } \\
\text { Deviasi }\end{array}$} & \multirow{2}{*}{ Mean } & \multirow{2}{*}{ Modus } & \multirow{2}{*}{ Median } & \multirow{2}{*}{ Min } & \multirow{2}{*}{$\operatorname{Max}$} & \multirow{2}{*}{$\%$} \\
\hline Rentang & Sikap & Jumlah & & & & & & & \\
\hline $8-14.3$ & Sangat tidak baik & I8 & & & & & & & $1.9 \%$ \\
\hline I $4.4-20.7$ & Tidak baik & I32 & & & & & & & $\mathrm{I} 4.3 \%$ \\
\hline $20.8-27 . I$ & Cukup & 536 & $4.8 \mathrm{I}$ & 24.72 & 25 & 25 & 8 & 39 & $57.9 \%$ \\
\hline $27.2-33.5$ & Baik & 204 & & & & & & & $22 \%$ \\
\hline $33.6-40$ & Sangat baik & 36 & & & & & & & $3.9 \%$ \\
\hline Total & & 926 & & & & & & & $100 \%$ \\
\hline
\end{tabular}

Pada tabel 4, data menunjukkan siswa cenderung berkategori cukup/netral dengan presentase siswa 65.2\%. Kemudian untuk siswa berkategori tidak baik sekitar I7\% siswa dan siswa yang berkategori baik sekitar I7.8\% siswa. Hal ini menunjukkan bahwa siswa masih bimbang dan kurang berminat untuk mendalami bidang fisika. 


\section{Ketertarikan Berkarir di Bidang Fisika}

Indikator tentang Ketertarikan Berkarir di Bidang Fisika di SMA daerah Batanghari dapat dilihat pada tabel di bawah.

Tabel 5. Indikator Ketertarikan Berkarir di Bidang Fisika

\begin{tabular}{|c|c|c|c|c|c|c|c|c|c|}
\hline \multicolumn{3}{|c|}{ Klasifikasi } & \multirow{2}{*}{$\begin{array}{l}\text { Standar } \\
\text { Deviasi }\end{array}$} & \multirow{2}{*}{ Mean } & \multirow{2}{*}{ Modus } & \multirow{2}{*}{ Median } & \multirow{2}{*}{ Min } & \multirow{2}{*}{ Max } & \multirow{2}{*}{$\%$} \\
\hline Rentang & Sikap & Jumlah & & & & & & & \\
\hline $\mathrm{I} 0-\mathrm{I} 7$ & Sangat tidak baik & II & & & & & & & $1.2 \%$ \\
\hline $18-25$ & Tidak baik & I46 & & & & & & & I5.8\% \\
\hline $26-33$ & Cukup & 604 & 5.69 & 32.6 & 32 & 30 & 10 & 55 & $65.2 \%$ \\
\hline $34-4 \mathrm{I}$ & Baik & I4I & & & & & & & $\mathrm{I} 5.2 \%$ \\
\hline $42-50$ & Sangat baik & 24 & & & & & & & $2.6 \%$ \\
\hline Total & & 926 & & & & & & & $100 \%$ \\
\hline
\end{tabular}

Pada tabel 5, data menunjukkan siswa cenderung berkategori cukup/netral dengan presentase siswa $65.2 \%$. Kemudian untuk siswa berkategori tidak baik sekitar I7\% siswa dan siswa yang berkategori baik sekitar $17.8 \%$ siswa. Hal ini menunjukkan bahwa siswa masih bimbang dan kurang berminat untuk mendalami bidang fisika.

\section{Masalah yang ditemukan dalam meningkatkan sikap di SMA Batanghari}

Berdasarkan analisis hasil angket tersebut, peneliti menemukan adanya beberapa siswa yang masih bermasalah di ke empat indikator yang diteliti.

Tabel 6. Indikator Sikap

\begin{tabular}{clc}
\hline No & \multicolumn{1}{c}{ Indikator } & Responden (926) \\
\hline I & Normalitas Ilmuan & $1.8 \%($ I7) \\
2 & Adopsi dari Sikap Ilmiah & $0.5 \%(5)$ \\
3 & Ketertarikan Memperbanyak Waktu Belajar & $17 \%(150)$ \\
4 & Ketertarikan Berkarir Dibidang Fisika & $17.8 \%(157)$ \\
\hline
\end{tabular}

Tabel 6 di atas menunjukkan data untuk indikator normalitas keilmuan terdapat sebanyak I.8\% atau sekitar 17 siswa berada pada kategori tidak baik. Pada indikator adopsi dari sikap ilmiah sebanyak $0.5 \%$ siswa atau sekitar 5 siswa berada dikategori yang sama. Kemudian terdapat juga siswa berkategori tidak baik pada Ketertarikan Memperbanyak Waktu Belajar Fisika dan Ketertarikan Berkarir di Bidang Fisika yakni berturut-turut sebanyak I7\% (I50 siswa) dan I7.8\% (I57 siswa).

\section{Diskusi}

Sikap positif maupun sikap negatif dapat muncul selama proses pembelajarannya. Sikap positif muncul karena adanya kinerja baik yang membangun harga diri siswa lebih tinggi dan menyebabkan minat pada subjek dan kinerjanya semakin meningkat [2I]. Sedangkan Sikap negatif bisa menjadi faktor dominan yang mempengaruhi kemauan siswa [22]. Hal tersebut akan mempengaruhi prestasi dan hasil belajar siswa. Berdasarkan hasil penelitian, sikap siswa SMA Batanghari terhadap fisika, secara umum siswa menunjukkan kecenderungan sikap ke arah positif dikeempat indikator. Berikut ini penjabarannya.

\section{Normalitas Keilmuan}

Hasil analisis tabel I dengan indikator normalitas ilmuan pada siswa di SMA Kabupaten Batanghari menunjukkan sebagian besar siswa berada pada kategori baik. Hasil angket mendeskripsikan bahwa siswa mampu menempatkan dirinya sebagai ilmuwan dan mencontoh pemikiran saintis saat belajar. Sedangkan hasil wawancara dipaparkan sebagai berikut.

Q: Apakah kamu mengenal ilmuan-ilmuan fisika? Jika ya, Menurut anda, bagaimana kehidupan para ilmuan-ilmuan tersebut dalam keseharian mereka?

J: Ya. Saya hanya tau sekedar nama dan jasa mereka. Misalnya seperti newton. kehidupan mereka, mungkin sama seperti manusia pada umumnya. Makan, tidur, bekerja, dan berkeluarga.

Q: Menurut anda, bisakah ilmuan memiliki pernikahan atau keluarga yang bahagia? Jelaskan alasannya!

J: Bisa. Mungkin. Saya kurang tau. Belum berpikir sampai kesana. Yang jelas, ilmuan kan sama juga seperti orang lain. Jadi kemungkinan ilmuan juga bisa bahagia. Kalo ilmuan dibilang tidak bisa punya 
keluarga atau pernikahan yang bahagia, pasti banyak yang menghindar jadi ilmuan.

Hasil wawancara tersebut, memperlihatkan anggapan siswa bahwa keseharian para ilmuwan itu normal. Siswa menganggap ilmuwan sebagai orang yang realistis [23], melakukan banyak hal seperti menemukan atau memecahkan masalah, unik, dan seorang yang pemikir [9]. Sebagian besar siswa tidak menganggap ilmuwan sebagai orang aneh ataupun anti sosial yang suka mengasingkan diri dari kehidupan masyarakat dan hanya berkutat di dalam laboratorium. Meskipun begitu, mereka masih belum paham mengenai profesi para ilmuan ataupun tidakan yang biasa dilakukannya.

\section{Adopsi dari sikap ilmiah}

Hasil analisis tabel 2 dengan indikator adopsi dari sikap ilmiah di SMA Batanghari, secara umum siswa berada dikategori baik. Siswa memiliki pemikiran yang kritis dan ilmiah untuk mendapatkan informasi baru yang didapatkan. Siswa cenderung penasaran dan terbuka dengan berbagai informasi diperoleh dari berbagai sumber. Berikut ini penjabaran hasil wawancara dengan siswa mengenai adopsi sikap ilmiah.

Q: apakah anda suka mendengar pendapat yang berbeda dari anda:Jelaskan alasannya!

J: ya saya suka mendengar pendapat yang berbeda dari pendapat saya. Karena, lewat pendapat yang berbeda itu, saya jadi bisa berpikir ulang lewat jalan yang berbeda. saya jadi semakin ingin tau kebenaran dari pendapat saya sendiri. Dan kalau pun salah, saya jadi lebih tau letak kesalahan saya.

Q: apakah anda suka mencari tau hal baru dan apa alasannya?

J: ya saya suka mencari tau hal baru. karena rasanya memberi efek menyegarkan. menyenangkan dan membuat saya penasaran. Saya jadi tau kalau masih banyak hal-hal yang belum saya ketahui. Pengetahuan saya juga bertambah dengan informasi yang baru.

Hasil wawancara menunjukkan bahwa siswa lebih terbuka dalam menerima opini orang lain. Terjadi interaksi antara sikap, kepercayaan dan kebiasaan [24]. Adanya rasa ingin tau akan kebenaran yang diyakini dan mengevaluasi hasil pengetahuannya sendiri memperlihatkan bahwa siswa memiliki sikap ilmiah yang baik. Selain itu, sikap sains siswa yaitu rasa keingintahuan siswa juga besar. Sikap tersebut mendorong siswa untuk penasaran, sehingga membuat siswa bertanya-tanya dan semangat siswa untuk menemukan jawaban permasalahan juga meningkat [25].
Deskripsi sikap siswa SMA di Batanghari berdasarkan indikator normalitas ilmuwan, adopsi dari sikap ilmiah, ketertarikan memperbanyak waktu, dan ketertarikan berkarir di bidang fisika

\section{Ketertarikan memperbanyak waktu belajar fisika}

Hasil analisis tabel 3 dengan indikator ketertarikan siswa SMA daerah Batanghari untuk memperbanyak waktu belajar fisika dikategorikan cukup. Mereka senang belajar di laboratorium, membaca artikel-artikel fisika atau sekedar menonton program fisika di televisi. Mereka tertarik untuk masuk kegiatan klub fisika. Namun mereka tidak terlalu suka jika harus menggunakan waktu libur mereka untuk belajar fisika. Oleh karena itu mereka berada dikategori rata-rata dan kurang tertarik untuk menambah waktu belajar fisika. Untuk hasil wawancara dipaparkan sebagai berikut.

Q: apakah anda sering belajar fisika sendiri dirumah? Jelaskan alasannya!

J: tidak, kadang-kadang saja seperti pada saat ujian saja saya belajar. Saya kurang berminat mempelajari fisika karena fisika terlalu sulit dan membosankan bagi saya.

Q: apakah anda membaca buku tentang fisika dirumah?

J:tidak saya memilih nonton tv dari pada membaca buku fisika.

Hasil wawancara menunjukkan bahwa siswa kurang tertarik untuk belajar fisika sehingga siswa tidak suka menambah waktu belajar mereka. Siswa yang memiliki sikap negatif terhadap suatu mata pelajaran, mereka tidak akan mau meluangkan waktunya untuk belajar mata pelajaran itu[26]. Siswa cenderung belajar jika ada tes atau ada tugas dari guru, mereka tidak berinisiatif sendiri untuk memperbanyak waktu belajar dirumah. Selain itu, siswa juga kurang tertarik untuk membaca buku pelajaran dan lebih suka menonton tv. Ini menunjukkan, siswa perlu diberikan lingkungan yang efektif untuk belajar dirumah. Lingkungan belajar mengajar fisika yang baik akan membuat siswa lebih memahami konsep fisika [17].

\section{Ketertarikan berkarir dalam bidang fisika}

Hasil analisis tabel 4 untuk indikator ketertarikan berkarir dalam bidang fisika di SMA daerah Batanghari menunjukkan siswa berada dikategori cukup. Siswa berfikir bahwa menjadi ilmuwan dan bekerja didalam laboratorium sangatlah menarik. Mereka memiliki ketertarikan untuk bekerja sama dengan penemu-penemu fisika. Namun kebanyakan siswa juga tidak berminat menjadi ilmuwan karena pendidikan yang harus ditempuh terlalu banyak dan akan sangat membosankan. Mereka juga tidak tertarik untuk mengajar fisika. Sedangkan untuk hasil wawancara siswa dipaparkan sebagai berikut.

Q: Apakah kamu berminat untuk berkarir di bidang fisika?

J: iya, saya ingin berkarit dibidang fisika tetapi tidak untuk menjadi guru karena menjadi guru merupakan pekerjaan yang berat. 
Q: Apa alasan anda tertarik dibidang fisika?

J: Karena jaman sekarang, Peran ilmu fisika sangat banyak dalam kehidupan. Jadi bidang fisika juga banyak dibutuhkan.

Hasil wawancara menunjukkan bahwa siswa siswa tertarik untuk berkarir dibidang fisika, namun bukan untuk mengajar. Menjadi guru fisika atau sejenisnya terlalu berat menurut mereka. Minat akan pencapaian karir dan kehidupan pribadi siswa [27]. Siswa yang berminat dengan pekerjaan-pekerjaan berhubungan dengan konsep fisika, mereka akan belajar lebih giat untuk memahaminya. Adanya kesempatan kerja yang luas dan kemungkinan kesuksesan yang besar dibidang fisika juga bisa menjadi faktor pendorong keinginan siswa untuk berkarir dibidang fisika.

\section{Kendala-kendala yang dihadapi}

Berdasarkan hasil analisis tabel 6, ditemui kendalakendala di setiap aspek indikator yang dibahas dalam penelitian ini. Sebanyak I.8\% siswa atau sekitar I7 orang siswa masih berada pada kategori tidak baik pada indikator normalitas ilmuwan. Hal tersebut dikarenakan kurang percaya diri dan memiliki pemikiran yang masih stereotip, menganggap fisika hanya dipelajari oleh orangorang yang terlahir jenius. Pada indikator adopsi dari sikap ilmiah, sebanyak $0.5 \%$ atau sekitar 5 orang siswa masih berkategori tidak baik. Hal tersebut dikarenakan kurangnya ketertarikan siswa terhadap fisika dan kurangnya respon siswa dalam belajar, sehingga kemampuan berpikir kritis dan keingintahuan siswa tidak berkembang.

Masalah lainnya juga muncul pada indikator ketertarikan memperbanyak waktu belajar siswa. Sebanyak I7\% atau sekitar I50 siswa berada pada kategori tidak baik. Siswa-siswa tersebut tidak tertarik untuk belajar mandiri di rumah ataupun menambah waktu belajarnya. Mereka cenderung malas untuk belajar karena pola pikirnya yang menganggap fisika itu sulit dan membosankan, dan siswa berkeyakinan bahwa mempelajarinya akan sia-sia karena pada akhirnya materimateri yang dipelajari tidak dipahaminya. Selain itu, Pada indikator ketertarikan untuk berkarir dibidang fisika terdapat sekitar $17.8 \%$ atau sekitar I57 orang siswa berada dikategori tidak baik. Siswa tersebut tidak ingin mempelajari lebih lanjut tentang fisika kedepannya. Siswa tersebut tidak berminat untuk berkarir di bidang tersebut karena mereka memiliki pencapaian dan belajar fisika yang rendah. Sehingga akan sulit kedepannya untuk menggeluti bidang yang siswa percayai bahwa bidang tersebut bukan keahliannya.
Deskripsi sikap siswa SMA di Batanghari berdasarkan indikator normalitas ilmuwan, adopsi dari sikap ilmiah, ketertarikan memperbanyak waktu, dan ketertarikan berkarir di bidang fisika

Pada bagian Pustaka, diberikan beberapa contoh yang relatif banyak digunakan oleh jurnal-jurnal internasional. Silahkan para penulis untuk menyesuaikan diri.

Pada bagian Pustaka, diberikan beberapa contoh yang relatif banyak digunakan oleh jurnal-jurnal internasional. Silahkan para penulis untuk menyesuaikan diri.

\section{Kesimpulan}

Berdasarkan penelitian yang telah dilakukan, indikator adopsi sikap ilmiah memiliki persentase berkategori baik paling tinggi dibandingkan indikator-indikator lain yang diukur. Hal tersebut memperlihatkan bahwa siswa SMA di batanghari memiliki rasa ingin tahu yang besar dan suka mencari pengetahuan baru. Pada indikator normalitas ilmuan, dominan berkategori baik karena siswa mengetahui bahwa ilmuwan fisika juga melewati proses belajar seperti orang normal lainnya, yakni mempelajari dan memahami dengan ulet hal-hal yang membuat mereka penasaran serta tidak takut gagal dalam bereksperimen. Pada indikator ketertarikan memperbanyak waktu belajar fisika berkategori cukup karena hanya belajar disaat mereka memiliki tugas atau akan menghadapi tes. Pada indikator ketertarikan berkarir dibidang fisika, siswa berkategori cukup dikarenakan mereka kurang tertarik untuk memperdalam ilmu fisika tetapi mereka berminat untuk bekerja dibidang-bidang yang berkaitan dengan fisika secara tidk langsung.

Kendala yang dihadapi dalam meningkatkan sikap siswa dalam pembelajaran fisika adalah rasa bosan dan pandangan negatif siswa terhadap fisika. Sikap positif terhadap pembelajaran fisika sangat membantu dalam memahami pelajarannya. Sehingga, guru perlu mengembangkan pembelajaran yang aktif dan dapat meningkatkan minat serta keingintahuan siswa sehingga sikap positif siswa akan meningkat dalam belajar. Selain itu, guru perlu mengkombinasikan pembelajaran berbasis eksperimen dan teori secara imbang agar pembelajaran dikelas tidak monoton. Keterampilan siswa dalam memecahkan permasalahan fisika pun perlu ditingkatkan. Sehingga, keterampilan yang baik akan mempermudah siswa untuk membentuk kebiasaan belajar yang baik [28].

\section{Kepustakaan}

[I] Ernawati, R., Sjarkawai dan Rayandra Asyhar, Pengaruh Penerapan Model Pembelajaran Kooperatif Tipe Group Investigation (GI) Terhadap Hasil Belajar dan Sikap Ilmiah Siswa pada Mata Pelajaran Fisika SMA, Tekno-Pedagogi, Vol. 2, No. 2, 2012, pp: 80-92

[2] Johari, A. H., and Muslim, Application of experiential learning model using simplephysical kit to increase attitude toward physics student senior high school in fluid. Journal of physics, vol.IOI3, 2018 
[3] Erdemir, N., Determining Students' Attitude Towards Physics Through Problem-Solving Strategy, In Asia-Pacific Forum On Science Learning And Teaching, vol. I0, No. 2, 2009, pp. I-I9.

[4] Fakhrudin, E. E., Student's Scientific Attitudes In Physics Learning Using The Use Of Computer Media Through A Model Co-Operative Model Type STAD On Students Of Class X3 Secondary School in Bangkinang Barat, Jurnal Geliga Sains, 20I0, pp. I-22.

[5] Kaya, H., \& Boyuk, U., Attitude Towards Physics Lessons And Physical Experiments Of The High School Students, European Journal Of Physics Education, vol.2, no.I, 201 I, pp. 23-3I.

[6] Rahman, Agus Abdul, Psikologi Sosial (Integrasi Pengetahuan Wahyu dan Pengetahuan Empirik), Jakarta, PT. Raja Grafindo Persada, 2014.

[7] Olusola, Olasimbo O. \& Rotimi, C.O., Attitudes Of Students Towards The Study Of Physics In College Of Education Ikere Ekiti, Ekiti State, Nigeria, American International Journal of Contemporaty Research, vol. 2, no.I2, 2012, pp. 86.

[8] Fransiska, Lidya, Undang Rosidin dan Abdurrahman, Pengaruh Persepsi Siswa tentang Saintis dan Sikap Ilmiah terhadap Hasil Belajar Fisika, Jurnal Pembelajaran Fisika Universitas Lampung, 2013, pp:77-90.

[9] Balçın, Muhammed Doğukan, \& Ayşegül Ergün, Secondary School Students' Perceptions and Attitudes about Scientists, European Journal of Education Studies, vol. 4, no. 4, 2018, pp. 66-93.

[I0] Christidou, Vasilia, Interest, Attitudes, and Images Related to Science: Combining Students' Voices with the Voices of School Science, Teachers, and Popular Science, International Journal of Envitonmental \& Science Education, vol. 6, no.2, 201 I, pp. I4I-I59.

[II] Damanik, Dede Parsaoran daan Nurdin Bukit, Analisis kemampuan berfikir kritis dan sikap ilmiah pada pembelajaran fisika menggunakan model pembelajaran Inquiry Training (IT) dan Direct Intruction (DI), Jurnal Online Pendidikan Fisika, vol. 2, no. I, 2013, pp. I6-25.

[I2] Bybee, R., Mccrae, B., \& Laurie, R., PISA 2006: An Assessment Of Scientific Literacy, Journal Of Research In Science Teaching, vol. 46, no. 8, 2009, pp. 865-883.

[13] Manasi, L., Enjoyment Of Learning In Upper Secondary Education. An Exploratory Research, Procedia-Social And Behavioral Sciences, 180, 2015, pp.639-646.

[I4] Visser, Y. L., Convergence and Divergence in Children's Attitudes toward the Sciences and Science Education, Florida Atlantic University, Learning Development Institute, 2007.

[15] Juan, A. R., Does it matter whether students enjoy learning science? Exploring student attitudes towards science in South Africa. Human Sciences Reseach Council, 2016, pp. I-6.

[16] Welch, A. G., Using The Tosra To Assess High School Students' Attitudes Toward Science After Competing In The First Robotics Competition: An Exploratory Study. Eurasia Journal Of Mathematics, Science \& Technology Education, vol.6, no.3, 2010.

[17] Veloo, A., Nor, R., \& Khalid, R., Attitude Towards Physics And Additional Mathematics Achievement Towards Physics Achievement. International Education Studies, vol. 8, no.3, 2015, pp. 35-43.
Deskripsi sikap siswa SMA di Batanghari berdasarkan indikator normalitas ilmuwan, adopsi dari sikap ilmiah, ketertarikan memperbanyak waktu, dan ketertarikan berkarir di bidang fisika

[18] Cresswel, John W. Educational Research: Planning, Conducting, And Evaluating Quantitative And Qualitative Research, New York, Pearson, 2012.

[19] Darmawangsa, Rio, Pengembangan Instrumen Sikap Siswa Sekolah Menengah Atas terhadap Mata Pelajaran Fisika, skripsi, Universitas Jambi, Jambi, 2018.

[20] Cohen, L., Manion, L., \& Morrison, K., Research Methods In Education, Routledge, 2005.

[2I] Akinbobola,Akinyemi Olufunminiyi, Enhancing Students' Attitude Towards Nigerian Senior Secondary School Physics Through The Use Of Cooperative, Competitive And Individualistic Learning Strategies. Australian Journal of Teacher Education, vol. 34, no. I, 2009, pp. I-9.

[22] Mbajiorgu, Ngozi dan Norman Reid, Factors Influencing Curriculum Development in higher Education Physics, England, HEA Physical Science Centre, 2006.

[23] Leblebicioglu, Gulsen, Duygu Metin, Esra Yardimci, \& Pinar Seda Cetin, The effect of informal and formal interaction between scientists and children at a science camp on their images of scientists, Science Education International, vol.22, no. 3, 20II, pp. I58-I74.

[24] Erdogan, Sezen Camci, Science Teaching Attitudes and Scientific Attitudes of Pre-service Teachers of Gifted Students, Journal of Education and Practice, vol. 8, no. 6, 2017, pp. I64I70.

[25] Mukhopadhyay, R., Scientific attitude-some psychometric considerations, IOSR Journal Of Humanities And Social Science (IOSR-JHSS) OSR-JHSS, vol. I9, 2014, pp. 98-100.

[26] DS, sitti hartinah \& Setiawan, T., Leadership Teachers Attituded to Mathematical Learning, Jurnal Ilmu Pendidikan, vol. I9. no.I, 2013.

[27] Arslan, N. I., High school students' educational and career interest (science-technology- mathematics) and career adaptabilities, Australian Council for Educational Research, 2015, I66-172.

[28] Karamustafaoğlu, S., Improving the science process skills ability of prospective science teachers using I diagrams. Eurasian Journal of Physics and Chemistry Education, vol. 3, no. I, 20I I, pp. 26-38.F. Bennett, D. Clarke, J. B. Evans, A. Hopper, A. Jones and D. Leask, Piconet: Embedded mobile networking, IEEE Personal Communications Magazine, vol. 4, no. 5, 1997 pp. 8-I5. 